7. Reprod. Fert. (1966) 12, 233-236

BRIEF COMMUNICATION

\title{
OESTROUS SYNCHRONIZATION AND PREGNANCY BLOCKING IN WILD HOUSE MICE (MUS MUSCULUS)
}

\author{
R, K. CHIPMAN AND K. A. FOX \\ Department of Zoology, The University of Vermont, \\ Burlington, Vermont, U.S.A.
}

(Received 11th March 1966)

\begin{abstract}
Summary. In wild female house mice a skewed distribution of vaginal plugs on the days following pairing indicates an oestrous synchronization (Whitten effect) correlated with the presence of the male. Inseminated wild house mice were exposed to strange males or subjected to various types of cage changes and handling during the pre-implantation period. The strange males produced a significant reduction in pregnancy rates (Bruce effect). Changes in the physical environment produced comparable reductions in the absence of a strange male.
\end{abstract}

Several socio-dependent reproductive phenomena are known to occur in some strains of laboratory mice. Two of these are the Whitten or oestrous synchronizing effect and the Bruce or pregnancy blocking effect (Parkes \& Bruce, 1961). The odour of a male is capable of stimulating the oestrous cycle, hence synchronizing the females so that a large percentage becomes inseminated on the 3rd night following pairing. Similarly the odour of a strange male will block implantation, following which the female will return to oestrus. The object of the present study was to determine the occurrence of these two phenomena in wild house mice maintained under laboratory conditions.

The mice used in this study were produced in an outbred laboratory colony derived from local stock. Wild-trapped animals were periodically added. Mice were fed a standard laboratory ration and housed in large-mouthed, 1-gal glass jars placed horizontally. A 4 in. diameter opening was cut in each jar top and fitted with a $\frac{1}{3}$ in. screen. This closure provided ventilation and access for the water bottle drinking tube. The wild house mice seem to adjust well to this 'cage'. Mice were weaned at 21 days of age and kept three to five per cage. Eight- to 12-week-old virgin females were placed with a stud male of proven fertility and examined each morning for vaginal plugs, which were considered evidence of insemination. The number of days between pairing and insemination was recorded and analysed for evidence of oestrous synchronization. Following insemination the male was removed and the female isolated for $24 \mathrm{hr}$ (Day 0). On Day 1 the females were randomly assigned to one of the eight treatments described in Table 2. Pregnancy was determined by autopsy and examination 
of the uteri for implantations on Day 7 . The data were compared by $\chi^{2}$ analysis.

The frequency distribution of vaginal plugs on the days after pairing is given in Table 1. Females housed since weaning in a room without males showed a distinct 3rd (31\%) and 4th (45\%) night peak of inseminations, a significant $(P<0.001)$ deviation from the theoretically equal distribution that would occur in the absence of a synchronizing effect. Females housed in a room

TABLE 1

FREQUENCY DISTRIBUTION OF VAGINAL PLUGS ON THE DAYS AFTER PAIRING

\begin{tabular}{l|cccccc|c}
\hline & \multicolumn{5}{|c|}{ Days after pairing } & \multirow{2}{*}{$\begin{array}{c}\text { No. } \\
\text { of } \\
\text { females }\end{array}$} \\
\cline { 2 - 6 } & 1 & 2 & 3 & 4 & 5 & 6 & 81 \\
\hline $\begin{array}{l}\text { I. Females kept in } \\
\text { separate room from } \\
\text { males before pairing }\end{array}$ & 6 & 12 & 23 & 34 & 4 & 2 & 81 \\
$\begin{array}{l}\text { II. Females kept in same } \\
\text { room with males before } \\
\text { pairing }\end{array}$ & 30 & 38 & 54 & 36 & 23 & 13 & 194 \\
\hline
\end{tabular}

TABLE 2

PREGNANCY RATES OF WILD HOUSE MICE SUBJECTED TO VARIOUS CONDITIONS OF HOUSING; STRANGE MALE PRESENT IN TREATMENT II ONLY

\begin{tabular}{c|c|c}
\hline \multicolumn{1}{c|}{ Treatment of females } & $\begin{array}{c}\text { No. } \\
\text { of females }\end{array}$ & $\begin{array}{c}\text { Percent } \\
\text { pregnant }\end{array}$ \\
\hline I. Isolated in stud cage for Days 0 to 7 & 50 & 76 \\
II. Housed with strange male for Days 1 to 5* & 50 & 16 \\
III. Transferred to a clean cage on Days 1 and 5 only & 75 & 56 \\
IV. Transferred to a clean cage and excited $\dagger$ daily \\
on Days 1 to 5 & 25 & 12 \\
V. Transferred to a clean cage on Days 2 and 3; & 25 & 28 \\
Excited on Days 3 and 4 $\begin{array}{l}\text { Transferred to a clean cage daily on Days 1 to 5 } \\
\text { VII. Cage contents disrupted twice daily by rolling }\end{array}$ & 25 & 40 \\
cage 360 on Days 1 to 5 & 25 & 36 \\
\hline
\end{tabular}

* Females were changed at 09.00 hours

$\dagger$ Females were excited at 17.00 hours by holding the animal by the dorsum and blowing upon it until the mouse urinated.

with males before pairing exhibited a more uniform distribution of inseminations with a slight peak of $34 \%$ on the 3rd night. The magnitude of the deviation from the theoretical distribution was considerably reduced but still significant $(P<0 \cdot 05)$.

The pregnancy rate of the fifty isolated females (controls) was $76 \%$ (Table 2). A strange male was clearly able to reduce this rate. However, comparable reductions were also accomplished by various conditions of cage changing and handling. In general, the extent of pregnancy blocking in the absence of the 
strange male was dependent on the degree of cage changing and handling of the females. Statistical comparisons of the various treatments are given in Table 3.

The observed frequency distribution of vaginal plugs establishes the existence of oestrous synchronization in wild house mice. This phenomenon is presumably of olfactory mediation since females previously housed in a room containing males failed to show as marked synchronization as those isolated from male odours. The high incidence of 4th night inseminations in wild house mice, in contrast to the 3rd night peak in laboratory strains, may be the result of an inherently longer oestrous cycle as suggested by data cited in Asdell (1964).

Enforced cohabitation with a strange male greatly reduces the pregnancy rate among recently inseminated wild females. Control treatments were necessary to determine if moving and handling of females could cause a reduction in the pregnancy rate. The results of treatment III suggest this possibility. Treatments IV to VI clearly demonstrate such an effect. In treatment VII the two daily disruptions of the cage contents without handling the

TABLE 3

PROBABILITY LEVELS ASSOCIATED WITH DIFFERENCES IN PREGNANCY RATES BETWEEN VARIOUS TREATMENTS

\begin{tabular}{c|ccccccc}
\hline Treatment & I & II & III & IV & V & VI & VII \\
\cline { 2 - 8 } I & - & $<0.001$ & $<0.025$ & $<0.001$ & $<0.001$ & $<0.005$ & $<0.001$ \\
II & & - & $<0.005$ & NS & NS & $<0.025$ & NS \\
III & & & - & $<0.005$ & $<0.025$ & NS & NS \\
IV & & & & - & NS & $<0.05$ & $<0.05$ \\
V & & & & & - & NS & NS \\
VI & & & & & & - & NS \\
VII & & & & & & & - \\
\hline
\end{tabular}

NS, Not significant $(P>0.05)$.

female caused a lowered pregnancy rate, not statistically different from the rate due to the presence of a strange male. These findings indicate the pre-implantation period in the wild house mouse to be extremely sensitive to changes in the physical as well as social environment.

There appear to be two possible ways by which block to pregnancy in wild house mice may occur. One is induced by the presence of a strange male. The second is due to changes in the physical environment complicated by handling. Changes in cage size alone have been shown to reduce the pregnancy rate in deermice (Peromyscus maniculatus) to the same degree as the strange male (Eleftheriou, Bronson \& Zarrow, 1962). Bronson, Eleftheriou \& Garick (1964) note the same reduced pregnancy rate in deermice $(P . m$. bairdii $)$ from exposure to either sex of a different subspecies $(P . m$. gracilis).

Since wild female house mice are extremely sensitive to both social and physical changes in the laboratory environment during the pre-implantation period, similar changes could adversely affect females in their natural environment. Higher-density populations 'of house mice show reduced reproductive rates with increased emigration and aggression (Anderson, 1961). The resultant 
strife and increased opportunity for females to contact strange males or their odours could adversely affect mice during the pre-implantation period and impair the reproductive success of the population. Pearson (1963) noted that in two, high-density, natural populations there was a general failure of adult females to become pregnant and an increase in the percentage of parous, nonpregnant females in the older age classes. Crowcroft \& Rowe (1958) showed that when females from confined populations were allowed to disperse into vacant areas, the reproductive rates increased. These reports suggest that changes in the social and physical conditions of the natural environment do affect the pregnancy rate of the wild house mouse during the extremely sensitive pre-implantation period.

This investigation was supported by Public Health Service Research Grant HD-01141.

\section{REFERENCES}

Anderson, P. K. (1961) Density, social structure, and nonsocial environment in house-mouse populations and the implications for regulation of numbers. Trans. N.Y. Acad. Sci., Ser. II, 23, 447.

Asdell, S. A. (1964) Patterns of mammalian reproduction, 2nd edn. p. 358. Cornell University Press, Ithaca.

Bronson, F. H., El.eftheriou, B. E. \& Garick, E. I. (1964) Effects of intra- and inter-specific social stimulation on implantation in deermice. 7. Reprod. Fert. 8, 23.

Crowcroft, P. \& Rowe, F. P. (1958) The growth of confined colonies of the wild house-mouse (Mus musculus L.): the effect of dispersal on female fecundity. Proc. zool. Soc. Lond. 131, 357.

Eleftheriou, B. E., Bronson, F. H. \& Zarrow, M. X. (1962) Interaction of olfactory and other environmental stimuli on implantation in the deermouse. Science, N.r. 137, 764.

PARKEs, A. S. \& BRUCE, H. M. (1961) Olfactory stimuli in mammalian reproduction. Science, N. $r$. $134,1049$.

Pearson, O. P. (1963) History of two local outbreaks of feral house mice. Ecology, 44, 540. 